\title{
ACUTE PLEUROPULMONARY COMPLICATIONS DETECTED BY COMPUTED TOMOGRAPHY FOLLOWING MYOCARDIAL REVASCULARIZATION
}

\author{
Francisco S. Vargas, Kiyomi K. Uezumi, Fabio B. Janete, Mario Terra-Filho, \\ Whady Hueb, Alberto Cukier and Richard W. Light
}

RHCFAP/3085

VARGAS FS et al. - Acute pleuropulmonary complications detected by computed tomography following myocardial revascularization. Rev. Hosp. Clín. Fac. Med. S. Paulo 57(4):135-142, 2002.

INTRODUCTION: Pleuropulmonary changes are common following coronary artery bypass grafting surgery performed with a saphenous vein graft, with or without an internal mammary artery. The presence of atelectasis or pleural effusions reflects the thoracic trauma.

PURPOSE: To define the postoperative incidence of changes in the lung and in the pleural space and to evaluate the influence of the trauma.

METHODS: Thirty patients underwent elective coronary artery bypass grafting surgery (8 saphenous vein grafts and 22 saphenous vein grafts and internal mammary artery grafts with pleurotomy). Chest tubes in the left pleural space were used in all internal mammary artery patients. On the second (day 2) and seventh (day 7) postoperative day, patients underwent a computed tomography, and pleural effusions were rated as follows: grade $0=$ no fluid to grade $4=$ fluid in more than $75 \%$ of the hemithorax. Atelectasis was rated as follows: laminar $=1$, segmental $=3$, and lobar $=10$ points.

RESULTS: All patients had pleural effusion or atelectasis. Between day 2 and day 7, the number of patients with effusions or atelectasis on the right side decreased $(P<0.05)$. The incidence of effusions on day 2 in the saphenous vein graft group $(87.5 \%)$ was higher $(P<0.05)$ than in the internal mammary artery group $(52.3 \%)$. The incidence of atelectasis in the lower right lobe decreased $(P<0.05)$ from $86.7 \%$ (day 2$)$ to $26.7 \%$ (day 7 ). The degree of atelectasis in both sides did not differ on day $2(P=0.42)$ but did on day $7(P<0.0001)$. There was a decrease in the atelectasis from day 2 to day 7 on the right side $(P<0.001)$, but not on the left $(P=0.21)$. On day 2 there was a relationship between atelectasis and effusion on the right $(P=0.04)$, but not on the left $(P=0.113)$.

CONCLUSION: The present series demonstrates that there is a high incidence of both minimal pleural effusion and atelectasis after coronary artery bypass grafting surgery, which drops on the right side from day 2 to day 7 post surgery. Factors that contribute to the persistence of changes on the left side include the thoracic trauma and the presence of chest tubes and pericardial effusion.

DESCRIPTORS: Atelectasis. Pleural effusion. Coronary artery bypass surgery.

Pleuropulmonary changes are common following coronary artery bypass grafting $(\mathrm{CABG})$ surgery $^{1-3}$. The surgery is performed with a saphenous vein graft (SVG) with or without an internal mammary artery (IMA) graft. The IMA has become the graft conduit of choice because of its improved survival and high long-term patency rate ${ }^{4}$. However, the postoperative incidence of pleural changes may be higher in patients who receive an IMA graft. We previously showed that on the seventh postoperative day, the incidence of pleural changes observed on the chest radiograph was about 40\% (SVG: 43\%;

From the Heart Institute (InCor), Hospital das Clínicas, Faculty of Medicine, University of São Paulo, Brazil.
IMA: $41 \%$ ) and by ultrasound is about 80\% (SVG: 70\%; IMA: 100\%), higher than the incidence of atelectasis observed on chest radiograph (about $30 \%)^{1-3}$.

The presence of atelectasis or pleural changes probably reflects the fact that the patient has been subjected to a thoracic trauma and that the intensity of the trauma is higher in IMA pa- 
tients. We hypothesized that the trauma is responsible for these changes. In that case, the patients undergoing left-sided pleurotomy (IMA grafts) should have a higher incidence of complications immediately after the surgery. We further hypothesized that recovery from these changes would take longer in the IMA patients.

The purpose of this project was to define the acute postoperative incidence of changes in the lung and pleural space identified by computed tomography and to determine the influence of trauma on the development of these complications.

\section{METHODS}

Thirty-seven consecutive patients undergoing elective CABG surgery at the Instituto do Coração (FMUSP) were selected for further study. After the surgery, 30 patients were retained on this protocol; 8 had undergone only SVG grafts with no excessive manipulation of the pleura (SVG group), and 22 patients had received at least one IMA graft with pleurotomy in addition to the SVG grafts (IMA group). The remaining 7 patients did not fit the criteria for continuing in the study.

Coronary bypass grafting was carried out through a midline sternotomy. Moderate hypothermia $\left(28^{\circ} \mathrm{C}\right.$ to $\left.30^{\circ} \mathrm{C}\right)$ was applied, and cardiopulmonary bypass was carried out with a disposable bubble oxygenator. The decision to use SVG or both grafts was made by the operating surgeon. Postoperatively, a small tube was used in all patients to drain the mediastinum. Chest tubes for draining the left pleural space were used in all IMA patients. Only patients with a normal chest radiograph before surgery were included in the study.

All subjects underwent computed tomography (CT) 48 hours after surgery (immediately after they had been dis- charged from the intensive care unit) and on the seventh postoperative day. Computed tomographic scanning was performed on a $4^{\text {th }}$ generation CT scanner (Tomoscan LX-Philips) with contiguous $10 \mathrm{~mm}$ collimation scans through the whole lung field. All images were obtained at the end of inspiration without contrast enhancement.

The CT scans were evaluated, and the presence or absence of pleural effusions and atelectasis was recorded. We considered laminar atelectasis to be any linear wedge-shaped parenchymal density without volume loss. Segmental or lobar atelectasis was identified when a trapezoidal or wedge-shaped parenchymal density occupied more than $50 \%$ of the corresponding segmental or lobar projection. Volume loss without parenchymal density was not included in this analysis because of difficulties in correct classification $^{5,6}$. We evaluated the degree of atelectasis semiquantitatively in each hemithorax by totaling the sums of the scores for lobar atelectasis (10 points per lobe), segmental atelectasis (3 points per segment) and laminar atelectasis ( 1 point per occurrence). The size of the pleural effusion was evaluated according to the follow- ing scale: grade 0 (no pleural fluid present) to grade 4 (pleural fluid occupying more than $75 \%$ of hemitho$\operatorname{rax})$.

Statistical analysis: data are expressed as the mean \pm standard deviation unless otherwise noted. Chisquare was used for statistical analysis when the proportion in the different groups was compared. Since the semiquantitative data for the atelectasis and pleural effusions were not normally distributed, we used the MannWhitney Rank Sum Test to compare groups. Probability values of less than 0.05 were regarded as significant.

\section{RESULTS}

The demographic characteristics of the two groups were very comparable (Table 1). The only significant difference $(P<0.05)$ was in age, but this was not felt to be clinically important. Only IMA patients received left chest tubes for draining the pleural space; tubes were left in place for $39 \pm 7$ hours, and the total volume drained was $200 \pm 62 \mathrm{~mL}$.

After CABG surgery, abnormalities on the CT scans were very common

Table 1 - Subjects and surgery characteristics.

\begin{tabular}{|c|c|c|c|}
\hline & $\begin{array}{l}\text { Saphenous Vein } \\
\text { Graft Group }\end{array}$ & $P<0.05$ & $\begin{array}{c}\text { Internal Mammary } \\
\text { Artery Group }\end{array}$ \\
\hline & Demographic Data & & \\
\hline $\mathrm{n}$ & 8 & & 22 \\
\hline Gender $(\mathrm{M} / \mathrm{F})$ & $6 / 2$ & & $17 / 5$ \\
\hline Age (yr) & $59.6 \pm 7.2$ & $*$ & $52.1 \pm 6.8$ \\
\hline Weight (kg) & $71.2 \pm 11.4$ & & $72.5 \pm 10.7$ \\
\hline \multirow[t]{2}{*}{ Smoke (pack/yr) } & $25.4 \pm 26.8$ & & $27.4 \pm 29.8$ \\
\hline & Times & & \\
\hline Anesthesia (min) & $348.3 \pm 79.4$ & & $339.2 \pm 68.2$ \\
\hline Pump (min) & $104.5 \pm 40.6$ & & $108.6 \pm 31.5$ \\
\hline Intubation (min) & $587.3 \pm 284.3$ & & $557.8 \pm 321.2$ \\
\hline \multirow[t]{2}{*}{ Left Chest Tube (hs) } & & & $39 \pm 7$ \\
\hline & Drained Volume & & \\
\hline Mediastinum (ml) & $319 \pm 85$ & & $303 \pm 72$ \\
\hline Left Pleural Space $(\mathrm{ml})$ & & & $200 \pm 62$ \\
\hline
\end{tabular}


Table 2 - Incidence of pleural effusion and atelectasis on Computed Tomography scan 2 and 7 days post-coronary artery bypass grafting surgery.

\begin{tabular}{|c|c|c|c|}
\hline & $\begin{array}{c}\text { Saphenous Vein } \\
\text { Graft Group }(\mathrm{n}=8)\end{array}$ & $\begin{array}{l}\text { Internal Mammary } \\
\text { Artery Group }(\mathrm{n}=22)\end{array}$ & $\begin{array}{l}\text { TOTAL } \\
(\mathrm{n}=30)\end{array}$ \\
\hline \multicolumn{4}{|c|}{$\underline{\text { PLEURAL EFFUSION }}$} \\
\hline \multicolumn{4}{|l|}{ Right Hemithorax } \\
\hline $2^{\text {nd }}$ day & $7(87.5 \%)$ & $10(45.5 \%)$ & $17(56.7 \%)$ \\
\hline $7^{\text {th }}$ day & $3(37.5 \%)$ & $4(18.2 \%)$ & $7(23.3 \%)$ \\
\hline \multicolumn{4}{|l|}{ Left Hemithorax } \\
\hline $2^{\text {nd }}$ day & $7(87.5 \%)$ & $13(59.1 \%)$ & $20(66.7 \%)$ \\
\hline $7^{\text {th }}$ day & $4(50.0 \%)$ & $15(68.2 \%)$ & $19(63.3 \%)$ \\
\hline \multicolumn{4}{|c|}{$\underline{\text { ATELECTASIS }}$} \\
\hline Right Hemithorax & & & \\
\hline $2^{\text {nd }}$ day & $6(75.0 \%)$ & $20(90.1 \%)$ & $26(86.7 \%)$ \\
\hline $7^{\text {th }}$ day & $2(25.0 \%)$ & $7(31.8 \%)$ & $9(30.0 \%)$ \\
\hline \multicolumn{4}{|l|}{ Left Hemithorax } \\
\hline $2^{\text {nd }}$ day & $6(75.0 \%)$ & $20(90.1 \%)$ & $26(86.7 \%)$ \\
\hline $7^{\text {th }}$ day & $5(62.5 \%)$ & $21(95.5 \%)$ & $26(86.7 \%)$ \\
\hline
\end{tabular}

(Table 2). All of the patients had either pleural effusion or atelectasis on the second postoperative day (day 2), and all but one IMA patient had an abnormal exam on the seventh postoperative day (day 7).

Pleural effusions: There was a high incidence of pleural effusions following CABG surgery (Table 2). On day $2,17(56.7 \%)$ of the patients had effusions on the right side and $20(66.7 \%)$ on the left side; 15 (50.0\%) of the patients had bilateral effusions. Between day 2 and day 7, the number of patients with effusions on the right side decreased, while the number of effusions on the left side stayed almost the same. The right side differed significantly from the left $\left(\mathrm{X}^{2}=10.3, P<\right.$ $0.01)$. This difference was primarily due to the fact that the effusions on the left persisted in the IMA group. The incidence of pleural effusion in the SVG $(87.5 \%)$ group tended to be higher on day 2 than in the IMA (52.3\%) group (14/16 sides vs $23 / 44$ sides, $\left.\mathrm{X}^{2}=5.11, P<0.05\right)$. However, by day 7 , the incidence of pleural effusion did not differ significantly (7/ 16 sides vs $19 / 44$ sides, $X^{2}=0.06, P=$ $0.79)$.
All pleural effusions were small (Table 3). On the right side on both day 2 and day 7, all the effusions (24/ 30 ) were classified as grade 1 , with the fluid occupying only the costophrenic angle. On the left side, only 2 pleural effusions $(2 / 20 ; 10 \%)$ in the SVG group were graded as 2 (small pleural effusion) on the day 2. However, the incidence of grade 2 effusions on day 7 increased to $8 / 19$ (42\%). Only 1 patient $(1 / 8 ; 12.5 \%)$ with effusion grade 2 was in the SVG group; 7 patients (7/ $8 ; 87.5 \%$ ) were in the IMA group.

Atelectasis: The incidence of atelectasis was even higher than the incidence of pleural effusion following CABG surgery (Table 2). On day 2, 26 $(86.7 \%)$ of the patients had atelectasis on the right side, and $26(86.7 \%)$ of the patients had atelectasis on the left side. Bilateral atelectasis were present in $24(80 \%)$ patients. Between day 2 and day 7 , the number of patients with atelectasis on the right side decreased, while the number of patients with atelectasis on the left remained constant. The differences in the two sides were statistically significant $\left(\mathrm{X}^{2}=22.4, P<\right.$ $0.001)$. The incidence of atelectasis

Table 3 - Semiquantitative evaluation of pleural effusions.

PLEURAL EFFUSION

\begin{tabular}{|c|c|c|c|c|c|c|c|c|c|}
\hline & \multicolumn{3}{|c|}{$\begin{array}{c}\text { Saphenous Vein } \\
\text { Graft Group }(n=8)\end{array}$} & \multicolumn{3}{|c|}{$\begin{array}{c}\text { Internal Mammary } \\
\text { Artery Group }(n=22)\end{array}$} & \multicolumn{3}{|c|}{$\begin{array}{l}\text { TOTAL } \\
(\mathrm{n}=30)\end{array}$} \\
\hline & \multicolumn{2}{|c|}{ Grade } & \multirow[t]{2}{*}{ Total } & \multicolumn{2}{|c|}{ Grade } & \multirow[t]{2}{*}{ Total } & \multicolumn{2}{|c|}{ Grade } & \multirow[t]{2}{*}{ Total } \\
\hline & 1 & 2 & & 1 & 2 & & 1 & 2 & \\
\hline \multicolumn{10}{|c|}{ Right Hemithorax } \\
\hline $2^{\text {nd }}$ day & 7 & & 7 & 10 & & 10 & 17 & & 17 \\
\hline $7^{\text {th }}$ day & 3 & & 3 & 4 & & 4 & 7 & & 7 \\
\hline \multicolumn{10}{|c|}{$\underline{\text { Left Hemithorax }}$} \\
\hline $2^{\text {nd }}$ day & 5 & 2 & 7 & 13 & & 13 & 18 & 2 & 20 \\
\hline $7^{\text {th }}$ day & 3 & 1 & 4 & 8 & 7 & 15 & 11 & 8 & 19 \\
\hline
\end{tabular}

Table 4 - Incidence of lower lobe atelectasis on Computed Tomography scan, 2 and 7 days post- coronary artery bypass grafting surgery.

\begin{tabular}{|c|c|c|c|}
\hline & $\begin{array}{l}\text { Saphenous Vein } \\
\text { Graft Group }(\mathrm{n}=8)\end{array}$ & $\begin{array}{c}\text { Internal Mammary } \\
\text { Artery Group }(\mathrm{n}=22)\end{array}$ & $\begin{array}{l}\text { TOTAL } \\
(\mathrm{n}=30)\end{array}$ \\
\hline \multicolumn{4}{|c|}{ RIGHT LOWER LOBE } \\
\hline $2^{\text {nd }}$ day & $5(62.5 \%)$ & $21(95.5 \%)$ & $26(86.7 \%)$ \\
\hline $7^{\text {nd }}$ day & $2(25.0 \%)$ & $6(27.3 \%)$ & $8(26.7 \%)$ \\
\hline \multicolumn{4}{|c|}{ LEFT LOWER LOBE } \\
\hline $2^{\text {nd }}$ day & $6(75.0 \%)$ & $20(90.9 \%)$ & $26(86.7 \%)$ \\
\hline $7^{\text {nd }}$ day & $4(50.0 \%)$ & $19(86.4 \%)$ & $23(76.7 \%)$ \\
\hline
\end{tabular}


was comparable in the two groups on both day 2 and day 7 .

Almost all the atelectasis were in the lower lobe (Table 4). The incidence in the right lower lobe decreased significantly $(P<0.05)$ from $86.7 \%$ (26/30) on day 2 to $26.7 \%$ (8/30) on day 7 . The incidence on the left side was similar $(P>0.05)$ on day $2(26 /$ $30 ; 86.7 \%)$ but did not decrease significantly as it did on the right side either in the SVG group or in the IMA group (23/30; 76.7\%).

Since the atelectasis varied from lobar atelectasis to laminar atelectasis, we also analyzed the degree of atelectasis semiquantitatively. When atelectasis were analyzed in this manner (Table 5), we found that the degree of atelectasis in the two sides did not differ significantly $(P=0.42)$ on day 2 , but it did differ significantly on day 7 $(P<0.0001)$. There was a significant decrease in the amount of atelectasis from day 2 to day 7 on the right side $(P<0.001)$, but there was no significant decrease in the amount of atelectasis from day 2 to day 7 on the left side $(P=0.21)$.

Relationship between pleural effusion and atelectasis: There appeared to be a significant relationship between the occurrence of atelectasis and pleural effusion. On day 2 there was a significant correlation between the degree of atelectasis and the degree of pleural effusion on the right $(r$ $=0.38, P=0.04)$, but not on the left $(r$ $=0.295, P=0.113)$. However, between day 2 and day 7, there was a signifi- cant relationship between changes in the degree of atelectasis and the degree of pleural effusion $(r=0.53, P=$ $0.0025)$. On day 7 there was not a significant correlation between atelectasis and pleural effusion on either the right $(r=-0.02, P=0.91)$ or on the left $(r=0.198, P=0.29)$.

\section{DISCUSSION}

The present series demonstrates that there is a high incidence of both pleural effusion and atelectasis after coronary artery bypass surgery. The predominance was of minimal pleural effusions that reduced in incidence on the right side from day 2 to day 7 . Similar results were found concerning atelectasis; high incidence of laminar atelectasis was observed in the lower lobes on day 2 . This incidence was reduced on the right side on day 7 .

The incidence of pleural effusion in the present series is about $65 \%$ on both day 2 and day 7 . This incidence is substantially higher than the $43 \%$ reported previously ${ }^{1}$ and lower than the nearly $90 \%$ observed subsequently from the same institution ${ }^{2}$. The probable explanation for the differences in the 3 reports is that the presence of pleural effusion was assessed only via chest radiograph in the first paper, while it was assessed by ultrasound in the second, and by computed tomography in the present study. Therefore, the nearly $65 \%$ incidence of pleural effusions in the present study could re-

Table 5 - Semiquantitative evaluation of atelectasis.

\begin{tabular}{|c|c|c|c|}
\hline & $\begin{array}{c}\text { Saphenous Vein } \\
\text { Graft Group }(\mathrm{n}=8)\end{array}$ & $\begin{array}{c}\text { Internal Mammary } \\
\text { Artery Group }(n=22)\end{array}$ & $\begin{array}{l}\text { TOTAL } \\
(\mathrm{n}=30)\end{array}$ \\
\hline \multicolumn{4}{|c|}{ Right Hemithorax } \\
\hline $2^{\text {nd }}$ day & $4.0 \pm 3.0$ & $3.9 \pm 3.4$ & $3.9 \pm 3.2$ \\
\hline $7^{\text {th }}$ day & $0.4 \pm 0.7$ & $0.9 \pm 1.8$ & $0.8 \pm 1.6$ \\
\hline \multicolumn{4}{|c|}{ Left Hemithorax } \\
\hline $2^{\text {nd }}$ day & $4.1 \pm 3.1$ & $4.6 \pm 3.3$ & $4.5 \pm 3.2$ \\
\hline $7^{\text {th }}$ day & $2.1 \pm 3.0$ & $4.2 \pm 3.5$ & $3.5 \pm 1.6$ \\
\hline
\end{tabular}

flect an improvement in surgical technique.

The explanation for the occurrence of pleural effusion after CABG surgery is unknown, but there are several possibilities.

First, the pleural effusion could be secondary to pulmonary edema, either cardiogenic, caused by heart failure, or noncardiogenic, caused by acute injury of the lung after cardiopulmonary bypass. An inflammatory response from contact activation triggers a cascade of cytokines that retain activated blood cells in the pulmonary circulation $^{7}$. Additionally, reperfusion injury in cold and ischemic lung tissue generates oxygen free radicals that modify the vascular permeability. In the other hand, fluid administration during cardiopulmonary bypass is dictated by the need to maintain adequate perfusion flow and reservoir volume. Sequestration of volume in the extravascular space reduces venous return and mandates replenishment through the cardiopulmonary bypass apparatus. Therefore, changes in volume may reflect the permeability of the vascular membrane; the increased vascular permeability resulting from these processes causes diffuse pulmonary edema and pleural effusion ${ }^{8}$. In general, pleural effusions caused by pulmonary edema either from heart failure or from acute lung injury are bilateral and approximately equal in size ${ }^{9}$.

In our opinion, pulmonary edema could be an important causative factor for the effusions, since $50 \%$ of the effusions on the day 2 day were bilateral. However, the reduction of the cardiac function causing a pleural effusion should be considered a remote possibility. Our patients did not present evidence of heart failure, and in our previous study in a similar population, the left ventricular ejection fraction 7 days after the surgery was normal $^{2}$; moreover, most of our patients 
$(92 \%)$ were in functional class 1 preoperatively. If some degree of heart failure is present immediately after the surgery, the reduction in the heart function should be short-lived, given that in the present series, the incidence of bilateral pleural effusion on the day 7 was only $16.7 \%$ (5/30). Therefore, if it exists, cardiac failure caused by surgical trauma rapidly improves, and heart function returns to normal values during the first postoperative days resulting in the absorption of the pleural fluid.

Second, the postcardiac injury syndrome has been suggested as an adjuvant to the formation of pleural effusions. We feel this possibility is unlikely, since the syndrome is usually manifested after the second or third week of surgery ${ }^{10}$.

Third, the lymphatic drainage from the pleural space could be decreased postoperatively, particularly in patients who received an IMA graft. During the mobilization of the IMA pedicle, the associated lymphatics are transected. This disruption could be expected to decrease the lymphatic clearance from the pleural space and result in the accumulation of pleural fluid $^{11}$. We believe that this explanation is unlikely, since the incidence of pleural effusion on day 2 tended to be higher in the SVG group.

Fourth, the presence of a chest tube could have led to a pleural inflammation and the development of the effusion. The results of the present study offer no support for this hypothesis.

Fifth, the performance of pleurotomy could have led to the accumulation of pleural fluid. The trauma during surgery could have damaged the thoracic structures and in particular the pleura such that the rate of pleural fluid formation was increased or the rate of fluid absorption was decreased or both. Previous studies assessing the relationship between pleurotomy and postoperative pleural effusions have been in conflict ${ }^{11-13}$. The present study does not provide any support for the contention that pleural effusions are related to the performance of pleurotomy. Even though all patients in the IMA group underwent pleurotomy, the incidence of pleural effusion was no greater in this group.

Sixth, the pleural effusion could be related to the pericardial inflammation. A possibility exists that the pericardial fluid flows directly into the pleural space, since Fukuo et al. ${ }^{14}$ showed the presence of numerous small fenestrations, which provide direct communication between the pericardial and the pleural cavities. Ikaheimo et al. ${ }^{15}$ demonstrated pericardial effusion by echocardiography in $63 \%$ of their patients 1 week after cardiac surgery. However, we previously demonstrated that there was no association between the presence of pleural and pericardial effusion but that the persistence of pericardial effusion was related to a persistence of a pleural effusion in the IMA group ${ }^{2}$. It is interesting to observe in the present series that the incidence of left pleural effusion in the IMA group did not decrease from day 2 (59.1\%) to day 7 (68.2\%). Two factors should be considered in the explanation of the persistence of a left pleural effusion on day 7. First, the chest tubes are removed on day 2 , allowing the accumulation of fluid into the pleural cavity, and second, pericardial effusion persisted.

Seventh, the development of a pleural effusion could be related to the presence of atelectasis, the most common pulmonary complication after cardiac surgery (up to 70\%) and more prominent in the dependent portions of the lung ${ }^{16}$. Surgical procedures including anesthesia during CAGB surgery with cardiopulmonary bypass significantly affect the mechanical properties of the lungs. Before cardiopulmonary bypass, the patient is sub- jected to sternotomy and chest wall retraction for surgical exposure. Pleurotomy, required for harvesting the internal mammary artery, produces a partial pneumothorax. During cardiopulmonary bypass, to allow cardiac asystole and surgical repair, the lungs are not ventilated and remain collapsed, below functional residual capacity; after cardioplegic arrest, pulmonary blood flow ceases. These changes facilitate the production of atelectasis and pulmonary edema ${ }^{17}$. For these reasons, the development of pleural effusions could be related to the presence of atelectasis.

A previous study ${ }^{18}$ showed that following abdominal surgery, pleural effusions were more common if atelectasis was present. Atelectasis has been recognized as a common postoperative complication after open-heart surgery. Wilcox et al. ${ }^{19}$ found roentgenographic evidence of atelectasis on the first postoperative day in $87.7 \%$ of the patients. Hurlbut et al. ${ }^{11}$ reported with the same methodology an incidence of nearly $50 \%$ on day 2 , decreasing to approximately $40 \%$ six days after the surgery. Recently, Daganou et al. ${ }^{20}$ reported evidence of atelectasis on chest radiographs in $51 \%$ of patients on the first postoperative day and in $25 \%$ on the fourth postoperative day. However, in the present study as well as in the study by Gale et al. ${ }^{21}$, there was no a clear relationship between the presence of atelectasis and the development of effusion.

From this study, we concluded that in these patients undergoing $\mathrm{CABG}$ surgery, the incidence of pleural effusion observed via computed tomography was about $65 \%$ both on day 2 and day 7 , and most of the pleural effusions were minimal. The incidence of pleural effusion on the right side dropped from day $2(56.7 \%)$ to day 7 (23.3\%). However, on the left side, the incidence did not change. The factors involved in the persistence of the left effusion 
included the previous removal of the chest tubes and the probable persistence of a pericardial effusion. No differences were observed between the SVG and IMA groups. The evaluation of atelectasis showed similar results. There was a high incidence of atel- ectasis $(86.7 \%)$, mainly the laminar type, on the lower lobes, with no differences between the right and left lung or between the SVG group and IMA group. The incidence of atelectasis dropped on the right side from $86.7 \%$ (day 2) to $30.0 \%$ (day 7) but not on the left side ( $86.7 \%$ on both days). These postoperative pleuropulmonary changes were caused by thoracic trauma, in particular by the effects of the inflammatory response to the cardiopulmonary bypass.
VARGAS FS e col. - Cirurgia de revascularização do miocárdio: complicações pleuro-pulmonares agudas caracterizadas por tomografia computadorizada de tórax. Rev. Hosp. Clín. Fac. Med. S. Paulo 57(4):135-142, 2002.

INTRODUÇÃO: O comprometimento pleuro-pulmonar é freqüente após cirurgia de revascularização do miocárdio independente do uso de veia safena ou de artéria mamária interna. A presença de atelectasias e derrame pleural tem sido atribuída ao trauma torácico.

OBJETIVOS: Definir a incidência do comprometimento pleuro-pulmonar observado através de tomografia computadorizada, analisando a influência do trauma no desenvolvimento destas complicações.
MÉTODOS: Trinta pacientes foram submetidos a cirurgia eletiva de revascularização do miocárdio (8 safena e 22 também mamária com pleurotomia). Foi drenada a cavidade pleural esquerda de todos os pacientes do grupo mamária. Realizada Tomografia Computadorizada do tórax no $2^{\circ}$ e $7^{\circ}$ dias pós-op, avaliando-se o derrame pleural ( 0 : sem líquido e 4 : derrame em mais de $75 \%$ do 
hemitórax) e atelectasias (laminar: 1, segmentar: 3 e lobar: 10 pontos).

RESULTADOS: Todos os pacientes apresentaram derrame pleural ou atelectasia. Entre o $2^{\circ}$ e o $7^{\circ}$ dia, o número de pacientes com derrame ou com atelectasia, no lado direito, diminuiu ( $\mathrm{p}<0.05$ ). A prevalência de derrames, no $2^{\circ}$ dia, no grupo safena, $(87.5 \%)$ foi maior $(\mathrm{p}<0.05)$ do que no grupo mamária (52.3\%). A prevalência de atelectasias no lobo inferior direito diminuiu ( $\mathrm{p}<0.05)$ de $86.7 \%$ ( $2^{\circ}$ dia) para $26.7 \%$ ( $7^{\circ}$ dia). O grau de atelectasias, em ambos os lados, não diferiu no dia $2(\mathrm{p}=0,42)$ mas sim no dia 7 ( $\mathrm{p}<0.0001)$. Houve diminuição das atelectasias do dia 2 para o 7 , à direita $(\mathrm{p}<0.001)$, mas não à esquerda $(\mathrm{p}=$ 0.21). Houve correlação (dia 2) entre as atelectasias e os derrames à direita $(\mathrm{p}=0.04)$, mas não à esquerda $(\mathrm{p}=$ 0.113). CONCLUSÃO: Este estudo evidencia alta prevalência de derrame pleural e atelectasias após cirurgia de revascularização do miocárdio, que se reduz à direita no $7^{\circ}$ dia de pós-operatório. Os fatores envolvidos na persistência das alterações à esquerda incluem o maior trauma torácico, ressaltando-se a drenagem e a presença de derrame pericárdico.

DESCRITORES: Atelectasia. Derrame pleural. Cirurgia de revascularização do miocardio.

\section{REFERENCES}

1. PENG MJ, VARGAS FS, CUKIER A et al. - Postoperative pleural changes after coronary revascularization. Comparison between saphenous vein and internal mammary artery grafting. Chest 1992;101:327-30.

2. VARGAS FS, CUKIER A, HUEB W et al. - Relationship between pleural effusion and pericardial involvement after myocardial revascularization. Chest 1994;105:1748-52.

3. VARGAS FS, CUKIER A, TERRA-FILHO M et al. - Influence of atelectasis on pulmonary function after coronary artery bypass grafting. Chest 1993;104:434-7.

4. ANGELINI GD, BRYAN AJ, WEST RR et al. - Coronary artery bypass surgery: current practice in the United Kingdom. Thorax 1989;44:721-4

5. NAIDICH DP, ZERHOUNI EA \& SIEGELMAN SS - Lobar collapse. In: Computed tomography and magnetic resonance of the thorax. $2^{\text {nd }}$ ed. New York, Raven Press. 1991. p.197232 .
6. WEBB WR, MÜLLER NL \& NAIDICH DP - HRCT findings of lung disease. In: High-resolution CT of the lung. New York, Raven Press, 1992. p. 24-50.

7. MASSOUDY P, ZAHLER S, BECKER BF et al. - Evidence of inflammatory responses of the lungs during coronary artery bypass grafting with cardiopulmonary bypass. Chest 2001;119:31-6.

8. GILBERT TB, BARNAS GM \& SEQUEIRA AJ - Impact of pleurotomy, continuous positive airway pressure and fluid balance during cardiopulmonary bypass on lung mechanics and oxygenation. J Cardiothorac Vasc Anesth 1996;7:844-9.

9. WEISS JM \& SPODICK DH - Laterality of pleural effusions in chronic congestive heart failure. Am J Cardiology 1984;53:951-4.

10.LIGHT RW - Pleural effusion due to miscellaneous disease. In: LIGHT RW. Pleural disease. $3^{\text {nd }}$ ed. Philadelphia, Lea, 1995. 
11.HURLBUT D, MYERS ML, LEFCOE M et al. - Pleuropulmonary morbidity: Internal thoracic artery versus saphenous vein graft. Ann Thorac Surg 1991;50:959-64.

12.LANDYMORE RW \& HOWELL F - Pulmonary complications following myocardial revascularization with the internal mammary artery graft. European J Cardiothorac Surg 1990;4:156-61.

13.OLEARCHYK AS \& MAGOVERN GJ - Internal mammary artery grafting. J Thorac Cardiovasc Surg 1986;92:1082-7.

14.FUKUO Y, NAKATANI T, SHINOHARA H et al. - Pericardium of rodents: pores connect the pericardial and pleural cavities. Anat Res 1988; 220:132-5.

15.IKAHEIMO MJ, HUIKURI HV, AIRAKSINEN J et al. - Pericardial effusion after cardiac surgery: Incidence, relation to the type of surgery, antithrombotic therapy and early coronary bypass graft patency. Am Heart J 1988;116:97-102.

16.SLADEN RN \& BERKOWITZ DE - Cardiopulmonary bypass and the lungs. In: GRAVLEE GP, DAVIS RF \& UTLEY JR. Cardiopulmonary bypass. Baltimore, Williams \& Wilkins, 1993
17.BARNAS GM, WATSON RJ, GREEN MD et al. - Lung and chest wall mechanical properties before and after cardiac surgery with cardiopulmonary bypass. J Appl Physiol 1994;76:16675 .

18.LIGHT RW \& GEORGE RB - Incidence and significance of pleural effusion after abdominal surgery. Chest 1976;69:621-6.

19.WILCOX P, BAILE EM, HARDS J et al. - Phrenic nerve function and its relationship to atelectasis after coronary artery bypass surgery. Chest 1988;93:693-8.

20.DAGANOU M, DIMOPOULOU I, MICHALOPOULOS N et al. Respiratory complications after coronary artery bypass surgery with unilateral or bilateral internal mammary artery grafting. Chest 1998;113:1285-9.

21.GALE GD, TEASADALE SJ, SANDERS DE et al. - Pulmonary atelectasis and other respiratory complications after cardiopulmonary bypass and investigation of aetiological factors. Canad Anaesth Soc J 1979;26:15-21.

Received for publication on September 04, 2001 